are very uncommon and are probably fewer than when other methods are used.

Reports advocating its use have been published including recent series of cases from the U.S.A., ${ }^{1}$ Uruguay, ${ }^{2}$ Holland, ${ }^{3}$ and Bri.ain. ${ }^{4}$ Complications have been negligible. One advantage of the operation, most commonly performed as a prophylactic measure during operations for other abdominal conditions, is that it avoids cutting across the appendix with the risk of infection that this entails, as when the ligated stump is buried in the wall of the caecum under a pursestring suture.

The principle of the operation is to turn the appendix completely outside in, as one does with the finger of a glove, so that it comes to lie in the lumen of the caecum. It is usually done by stripping the appendix of its mesentery and turning in its tip with a probe, which is advanced until the appendix has completely disappeared into the interior of the caecum, leaving only a tiny depression. This is oversewn with a nonabsorbable cross-stitch which also includes any remaining blood vessels going to the appendix, which will then slough off and be digested. Radiographic studies show that this happens after a week or so. In any event appendicitis cannot occur because of the changed anatomy.

Gynaecologists have most opportunity of incidental elimination of the appendix, and it has been my routine to do so in all appropriate cases during pelvic surgery. I have employed the inversion technique exclusively since 1958 and have used it over 1,000 times. In no case has there been any postoperative complication whatever and I am unaware of any at a later date. Colleagues who have adopted the same procedure have had similar results. I therefore support the view of Edelbohls $s^{5}$ who in 1895 wrote: "Inversion of the normal appendix is so simple and easy a matter, withal in itself so devoid of danger, that the writer is prepared to advocate inversion of the appendix whenever for any reason the abdomen is opened. There are those surgeons who under the conditions just stated advocate ligature and removal of the normal appendix. How much more does their logic apply to the inversion of the entire appendix as contrasted with ligature and ablation." -I am, etc.,

Maternity Hospital,

Queen Elizabeth Medical Centre,
Birmingham

Hallatt, J. G., American fournal of Obstetrics and Gynecology, 1958, 75, 1043 .

Lopez, M. B. R., Archivos des Ginecologia Obstetricia del Üruguay, 1962, 20, 140.

3 Aartsen, E. T., Nederlandsch Tydschrift voor

Verloskunde en Gynaecologie, 1966, 66, 100.

Young, H. B., and Godhead, B,, fournal of $1972,17,55$.

Edelbohls, G. M., American foumal of the Medical Sciences, 1895, 109, 650 .

\section{Multiple Prescribing}

SIR,-It has been said that geriatrics is the art of taking patients off tablets. In the example I am reporting your readers may like to work out which tablets were treating the effects of others and in what order they were accumulated.

The patient, a 75-year-old woman whom I was asked to see at home because she was "arthritic and becoming unable to cope," was sitting in a chair, mildly confused, incontinent of urine, and un- willing to walk because she had been falling often The only physical abnormality of note was osteoarthritis of the knees. She said she was "on rather a lot of pills but was managing to get them all down." Inspection of her bedside table revealed tablets containing the following: (1) dextropropoxyphene and paracetamol; (2) phenylbutazone; 3) aspirin, codeine, and caffeine; (4) aspirin, mag nesium carbonate, and aluminium glycinate; (5) aluminium hydroxide; (6) dicyclomine hydro chloride, doxylamine succinate, and pyridoxine hydrochloride; (7) alkaloids of belladonna leaf ergotomine tartrate, phenobarbitone; (8) medazepam; (9) prochlorperazine; (10) calcium lactate; (11) sodium chloride; (12) Senokot; (13) ferrou sulphate; and (14) proteolysed liver and vitamin $B_{12}$. There were also liquid paraffin; chlorpromazine linctus; and a "vegetable treatment fo radish, parsley, lettuce, and mint.

This patient was taking a total of 26 different drugs together with a liver paté and salad. Should this be entered in the Guiness Book of Records? She was admitted to hospital, all tablets were stopped, and she returned home fully mobile 10 days later.-I am, etc.,

St. George's Hospital.

JOHN M. VARNEY

\section{Intradermal Influenza Vaccination}

SIR,-The possibility of achieving satisfactory immunization against influenza with a small intradermal dose of vaccine has obvious attractions, as Dr. J. D. Avison has pointed out (10 November, p. 358). Tauraso and others ${ }^{1}$ showed that $0.1 \mathrm{ml}$ of killed vaccine given intradermally with syringe and needle produced as good an antibody response as a standard $0.5-\mathrm{ml}$ subcutaneous dose, but this method is unsuitable for mass vaccination. Jet injectors can be adjusted to deliver intradermally but the entire dose may not always be implanted in the skin, and their use in this way for vaccination with killed vacines has been criticized.2 3 Recently we were able to assess this method using a Portojet gun. Though the results were not clear cut we think they are worth recording.

In two local boarding schools, one with 600 boys and the other with 240 girls, influenza immuniza tion has been carried out each October fo several years by the Schuco Jet Injection Service. In 1973, owing to manufacturing difficulties, there was insufficient vaccine to give both schools the usual 1-ml dose, so a decision was made to give a reduced dose intradermally. A volume of $0.15 \mathrm{~m}$ was chosen on Schuco's recommendation, based on experiments showing that a leakage of $0.05 \mathrm{ml}$ may expur with this meth occur with this method. Simultaneously a trial was conducted on 87 volunteers ( 51 boys, 8 girls, and 28 staff). They were divided into two groupsthose born on odd dates were given $1 \mathrm{ml}$ Admune
vaccine subcutaneously, and those born on even vaccine subcutaneously, and those born on even
dates $0.15 \mathrm{ml}$ of the same vaccine or $0.15 \mathrm{ml}$ dates $0.15 \mathrm{ml}$ of the same vaccine or $0.15 \mathrm{ml}$
Influvac intradermally. Each $1 \mathrm{ml}$ Admune conInfluvac intradermally. Each $1 \mathrm{ml}$ Admune con$98926 / 70$, and 100 IU B/Hong Kong/8/73. Thus

TABLE I-Antibody Responses

\begin{tabular}{ll|c|c|c|c}
\hline \multicolumn{2}{c|}{ Vaccine Dose } & $\begin{array}{c}\text { No. of } \\
\text { Persons } \\
\text { Tested }\end{array}$ & \multicolumn{2}{|c}{ No. (\%) with 4-fold rise of H.I. Antibody } \\
\cline { 3 - 6 } & A/Eng/42/72 & B/Eng/1/68 & B/HK/5/72 \\
\hline $1 \mathrm{ml}$ subcutaneous $\ldots$ & $\ldots$ & 37 & $14(38)$ & $10(27)$ & $8(22)$ \\
$0 \cdot 15$ ml intradermal.. & $\ldots$ & 50 & $12(24)$ & $10(20)$ & $7(14)$ \\
\hline
\end{tabular}

TABLE II-Mean (Geometric) H.I. Antibody Titres before and after Vaccination

\begin{tabular}{|c|c|c|c|c|c|c|c|c|}
\hline \multirow{2}{*}{\multicolumn{2}{|c|}{ Vaccine Dose }} & \multirow{2}{*}{$\begin{array}{l}\text { No. of } \\
\text { Persons } \\
\text { Tested }\end{array}$} & \multicolumn{2}{|c|}{ A/Eng/42/72 } & \multicolumn{2}{|c|}{ B/Eng/1/68 } & \multicolumn{2}{|c|}{$\mathrm{B} / \mathrm{HK} / 5 / 72$} \\
\hline & & & Before & After & Before & After & Before & After \\
\hline $\begin{array}{l}1 \mathrm{ml} \text { subcutaneous } \\
0.15 \mathrm{ml} \text { intradermal }\end{array}$ & 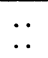 & $\begin{array}{l}37 \\
50\end{array}$ & $\begin{array}{r}105 \\
81\end{array}$ & $\begin{array}{l}263 \\
175\end{array}$ & $\begin{array}{l}12 \\
14\end{array}$ & $\begin{array}{l}30 \\
36\end{array}$ & $\begin{array}{l}2 \cdot 2 \\
2 \cdot 6\end{array}$ & $\begin{array}{l}8.6 \\
8.9\end{array}$ \\
\hline
\end{tabular}

$0.15 \mathrm{ml}$ Admune contained 60,15 , and $15 \mathrm{IU}$ of the three viruses respectively. Each $0.15 \mathrm{ml}$ of the Duphar vaccine contained 120 IU A/England T/72, 60 IU B/Berkeley/1/71, and 60 IU B/Hong Kong/8/73. Blood samples from the volunteers tests were run in parallel on the paired sera against three virus antigens: A/England/42/72, B/England/ $1 / 68$, and $B /$ Hong Kong/5/72. The method used was that described by Hoskins ${ }^{4}$ in which the reagents are used in $0.25-\mathrm{ml}$ amounts in W.H.O.type plastic agglutination trays.

Fewer people in the intradermal group showed four-fold or greater rise of antibody to the three viruses than the subcutaneous group (table I), but the differences were not statistically significant. In the case of virus A preinoculation titres were generally high and this may have modified the overall antibody response, for even in the subcutaneous groups only about one-third of the subjects showed a four-fold antibody rise. Response to the B viruses was poor in both groups, even though initial antibody titres were low, and the proportion of the subcutaneous control group found by Schild and his colleagues. 5 We can that no explanation for this. Within the intraderma group responses to the Admune and Influvac vaccines were not significantly different, though surprisingly there seed to be less respont though vaccine containing the larger amount of virus (Influvac). Reactions to intradermal inoculation were minimal and local discomfort less than with subcutaneous jet inoculation; also the need for preliminary skin testing of "allergic" patients was eliminated.

We believe that the economic and other advantages of this method merit its further assessment and that on existing evidence its use might well be justified when vaccine supplies are limited.-We are, etc.,

\section{K. PAYLER}

M. B. SKIRROW

Malvern,

Public Health Laboratory,

Tauraso, N. M., et al., Bulletin of the World Health Organization, 1969, 41, 507.

3 Roberts, T. E., British Medical fournal, 1973 4,738 .

Hoskins, J. M., Virological Procedures, chap. 20 London, Butterworth, 1967

1973, 4, 127., et al., British Medical fournal,

\section{Self-administered Clinical Questionnaires} for Outpatients

SIR,-Reading Drs. J. M. Gumpel and A. M. S. Mason's interesting paper (27 April, p. 209) on medical questionnaires made me wonder again why they are so slow to catch on. Patients like them, and once one has used them in a clinic there is a real sense of deprivation if they are not available. It may be just conservatism that has delayed their more widespread acceptance, but I think the real reason is the feeling that forms equate with bureaucracy, a condition rightly were taken at the time of the inoculation and again 
regarded as incompatible with clinical medicine.

The construotion of questionnaires remains a ticklish problem. I have recently attempted to simplify my own questionnaire ${ }^{1}$ by identifying and rejecting redundant questions. A correlation matrix was drawn up from 100 consecutive completed forms. The matrix showed which pairs of questions were or were not obtaining substantially the same information from the patient. If they were, then one of the pair could be left out. Furthermore, even elementary cluster analysis of the matrix revealed significan grouping of symptoms. "Neurotic" and "senile" groups were easily definable, and a more detailed factorial analysis is at present being undertaken. The emergence of factors -that is, symptom patterns-raises interesting questions as these do not always seem to correspond to our preconceived notions of so-called objective diagnoses.

Anyone who uses questionnaires will soon find himself fascinated and stimulated by the light they throw on the theory and practioe of the medical interview. - I am, etc.,

Exeter

G. H. HALI

1 Hall, G. H., British Medical foumal, 1972, 1, 42.

Radiographic Location of the Dalkon Shield

SIR,-The use of radiographic methods to establish the possible expulsion or translocation of a Dalkon Shield entails considerable irradiation of the patient, especially if one of the "soft tissue" techniques suggested by Dr. Ursula E. Mountrose and Mr. L. Whitehouse (1 June, p. 503) is used and both anteroposterior and lateral films are taken.

In the majority of cases an ultrasonic scan of the uterus through a full bladder is all that is required.12 The procedure is quick, simple, and free from harmful irradiation.

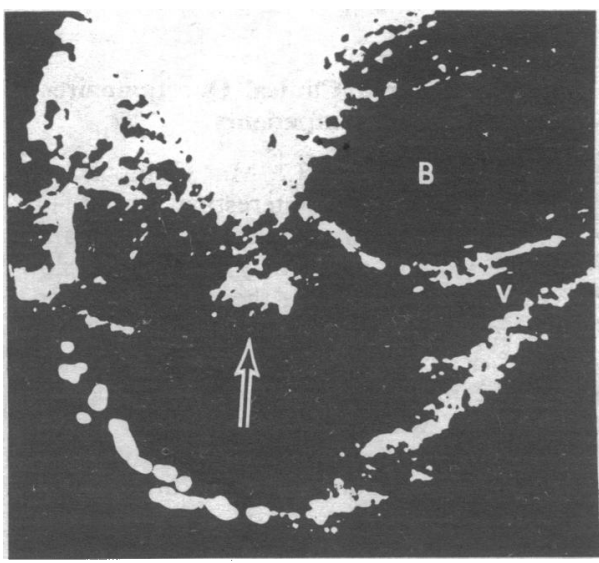

The Dalkon Shield in the uterus is arrowed. The vagina (V) and bladder (B) are clearly seen.

All types of intrauterine devices can be readily shown (see fig.). If the uterus is empty, then $x$-rays will of course be necessary to exclude translocation.-I am, etc.,

G. B. Young

Department of Radio-Diagnosis, Simpson Memorial Maternity Pavilion,

Royal Infirmary, Edinburgh 1 Cochrane, W. H., and Thomas, M. A., Radiology,

2 Mackay, D., and Mowat, J., Lancet, 1974, 1,

\section{Lactose Intolerance in San Populations}

SIR,-In a recent paper (6 April, p. 23) we described the investigation of a San ("Bushman") population for lactose tolerance and animadverted on the possibility (to which others ${ }^{12}$ have drawn attention) that the supplementation with dried milk of the diet of peoples in which adult tolerance of lactose is very unusual might be inadvisable. We have recenily investigated two further Khoisan peoples by the same methods and present a brief summary of our findings.

The populations investigated were:

(1) the thuâ:, a small San group found scattered in southern Botswana, the subject of some speculation regarding the affiliations of their language, which appears not to fall into any of the hitherto reorganized Bush groups; 3 and (2) the Nama of Keetmanshoop, representatives of the largest extant group of Khoi ("Hottentots"), resident in the semi-desert south of South-west Africa. The thuâ:, like the ! Kung, are not known ever to have been cattle-keepers or milkdrinkers; some of them do, however, live in a client/patron relationship with cattlekeeping Kgalagadi, and the latter, in common with the other Tswana, use both fresh and sour milk." The Khoi peoples first enter recorded history ${ }^{5}$ as cattle-keepers, and though the Nama of Keetmanshoop today possess few bovine cattle they do have an abundance of goats, whose milk they drink bath fresh and sour.

Lactose tolerance tests were performed on 34 thuâ:, but nine were excluded from the final calculations because of close family relationship or technical faults. Of the remaining 25, two proved to be tolerant, giving a phenotypic frequency for lactose tolerance of $8 \%$. With the exception of three children about 10 years old, all of them intolerant, all persons in the thuâ: series were adult. Among the Keetmanshoop Nama the results, after the exclusion of closely related individuals, showed a $50 \%$ frequency among children (4 out of 21); the difference was significant at the $5 \%$ level $(x=4 \cdot 18$ for 1 D.F.).

The frequency of lactose-tolerant individuals in San populations seems to be turning out to be rather higher than the hypothesis put forward by Simoons, ${ }^{6}$ that lactose tolerance represents an advantageous adaptation consequent on the development of dairying, would lead one to expect. Moreover, the significant difference between adults and children among the Nama would appear to favour the possibility that induction of lactase in response to milk-drinking plays a larger part in the production of adult tolerance than has previously been supposed, were it not that the youngest member of our series, a 7-year-old, was lactose tolerant. It seems to us that our latest findings may b: of some interest in the study of human evolution.

We should like to thank the Director, Professor T. F. Murray, and the Deputy Director, Professo Metz, of The South African Institute for Medical Research, as well as the Directors of Medical Services of Botswana and South West Africa, the medical superintendent and staff of Keetmanshoop Hospital and the District Surgeon, Keetmanshoop the Rev. Fr. Jansen, the Sister Superior and staff the Rev. the Don Bosco Nama Laerskool, Keetmanshoop, Mr. Thompson of the S.A.I.M.R. Laboratories in Ceetmanshoop, Mr. Tony Traill, the Ministry of Commerce and Industry, Gaborone, Botswana, and, of course, the 77 volunteers who made the
whole project possible. The work of the unit is supported in part by the Medical Research Council of South Africa.

-We are, etc.

G. T. NURSE TREFOR JENKINS

Human Sero-Genetics Unit,

South African Institute for Medical Research

and University of the Witwatersrand,

1 Cook, G. C., and Kajubi, S. K., Lancet, 1966 , 1, 725. C., and Kajubi, S. K., Lancet, 1966, Jersky, J, and Kinsley, R. H

Traill, A. African Studies, 1973, 32,25

Schapera, I., The Tswana. London, International African Institute, 1953.

5 Nienaber, G. S., Hottentots. Pretoria, Van Schaik, 1963. Simoons, F. J., American fournal of Digestive
Diseases, 1970, 15, 695.

\section{B.M.A. and B.M.S.A.}

SIR, - On behalf of past members of the British Medical Students Association, we would like to express our sincere gratitude to the B.M.A. for all the help that they gave the association over the years. We would also like to thank Mr. A. E. Vince for his hard work and forbearance in dealing with our many problems.-We are, etc.,

H. G. STURzaker

J. E. P. SIMPSON ALAN BAILEY MichaEL GARRAWAY

Harrow, Middlesex

\section{Temporarily Dependent Patients in General Practice}

SIR,-I would like to reply to the letters of Drs. Joyce E. Leeson and R. J. Robertson (18 May, p. 385). It is impossible to say whether the patients described in my article (30 March, p. 625) are ill or not ill in the absence of a universally acoepted definition of illness; hence my use of such terms as "undiagnosed," "succesfully untreated," and "ill in the accepted sense of the word."

These patients were called "temporarily dependent" because, having come to their doctor with no objective evidence of disease and having been given no pharmacologically effective treatment, they made no further effort to seek help either by returning to me, as they were invited to do, or to any of my three partners, as they could easily have done. The implication is that in that particular situation at that particular time they were in a state which was altered and improved by reassurance from their doctor. Dr. Robinson's point is well taken. It would have been more accurate to say "patients who received no pharmacologically effective treatment."- -I am, etc.

Portsmouth

К. В. THOMAS

\section{Drugs and Xylose Absorption from} Intestine

SIR,-Absorption of xylose from the human intestine has been reported ${ }^{1}$ to be decreased by metoclopramide and increased by propantheline. These drugs also alter the absorption of paracetamol ${ }^{2}$ and digoxin. ${ }^{3}$ These effects were thought to be due to delayed gastric emptying ${ }^{2}$ or to altered gastrointestinal motility. ${ }^{3}$ The indirect evidence quoted in support of this view does not ex- 